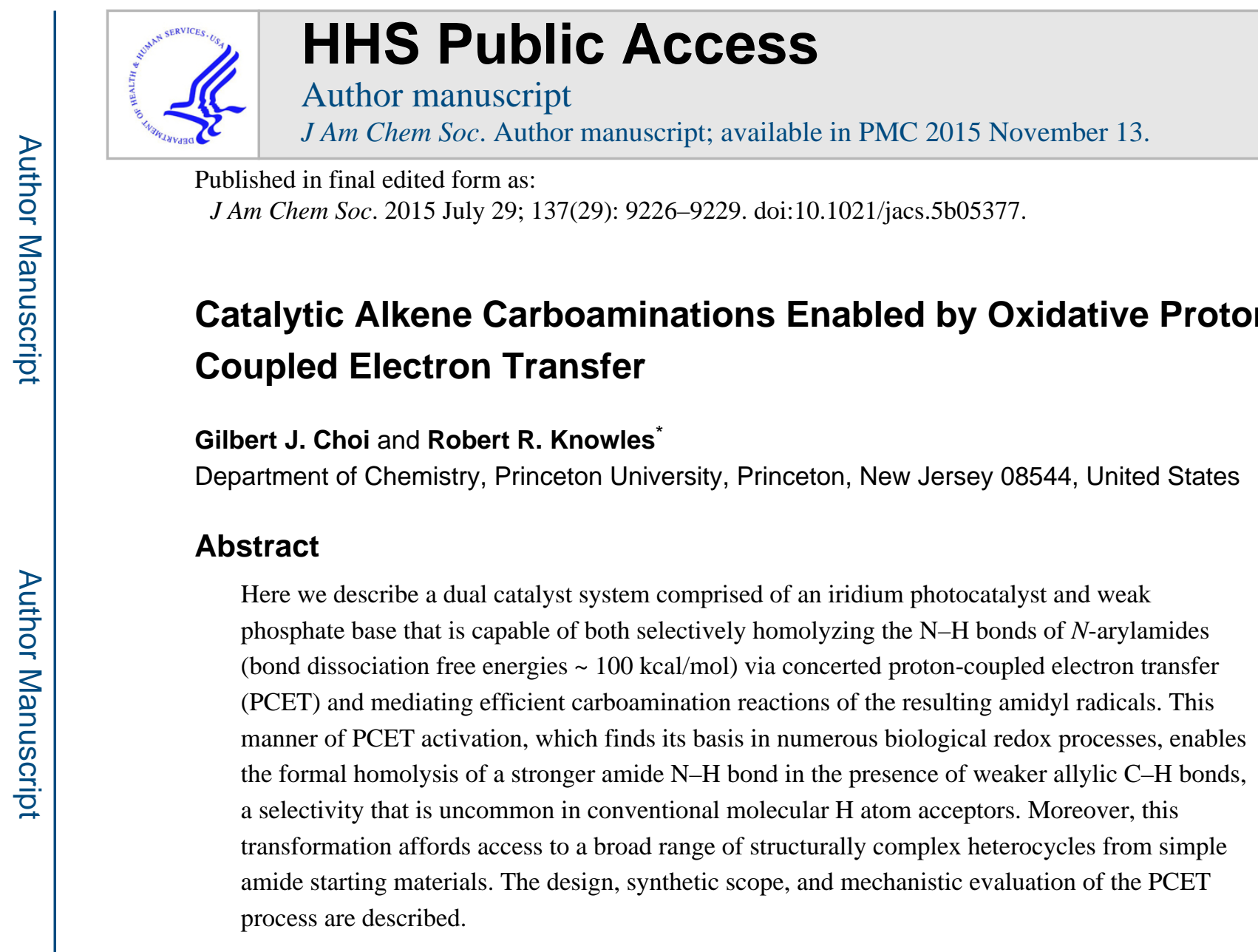

\begin{abstract}
Hydrogen atom transfer (HAT) is a powerful mechanism for homolytic bond activation that plays a central role in organic free radical chemistry. However, in HAT reactions involving conventional acceptors, such as main-group radicals and high-valent metal oxo complexes, the rates of abstraction are highly correlated with the strengths of the bonds being broken. ${ }^{1}$ In turn, this has limited the development of catalytic HAT methods that enable the selective homolysis of strong $\mathrm{E}-\mathrm{H}$ bonds found in many common organic functional groups, such as alcohols and amides, in preference to weaker $\mathrm{C}-\mathrm{H}$ bonds present in the same substrates. ${ }^{2}$
\end{abstract}

We recently questioned whether proton-coupled electron transfer (PCET) could serve as an alternative mechanism for homolytic bond activation that addresses this limitation. ${ }^{3}$ In PCET oxidations, an electron and proton originating from a single donor are transferred to two independent acceptors - a Brønsted base and a one-electron oxidant-in a concerted elementary step. While these exchanges constitute a formal loss of $\mathrm{H} \cdot$ and furnish a neutral free radical product in a manner similar to HAT, the chemoselectivities and energetic characteristics of PCET reactions are distinct. First, multisite PCET oxidations require the formation of a hydrogen bond between the transferring proton and the Brønsted base prior to electron transfer. ${ }^{4}$ As typical C-H bonds are poor hydrogen-bonding partners, we postulated

\footnotetext{
“Corresponding Author: rknowles@princeton.edu.

The authors declare no competing financial interest.

ASSOCIATED CONTENT

Supporting Information

Experimental procedures and characterization data. The Supporting Information is available free of charge on the ACS Publications website at DOI: 10.1021/jacs.5b05377.
} 
that PCET might enable the homolytic activation of stronger $\mathrm{O}-\mathrm{H}$ and $\mathrm{N}-\mathrm{H}$ bonds selectively via the formation of more favorable non-covalent complexes. Moreover, these hydrogen-bonding interactions should significantly decrease the potential requirements for the electron transfer process, enabling the use of comparatively mild one-electron oxidants. ${ }^{5}$ Lastly, the driving force for the PCET step can be rationally modulated over a wide range of energies by independently varying the $\mathrm{p} K_{\mathrm{a}}$ of the proton acceptor and the reduction potential of the oxidant (vide infra). ${ }^{6}$ Taken together, these attributes provide a basis for the rational identification oxidant/base combinations that are thermodynamically competent to selectively homolyze strong E-H bonds with bond dissociation free energies (BDFEs) in excess of $100 \mathrm{kcal} / \mathrm{mol}$.

In line with the above ideas, we report here a dual oxidant/base catalyst system for oxidative PCET activation of the strong $\mathrm{N}-\mathrm{H}$ bonds in $N$-arylamide derivatives (N-H BDFEs $~ 100$ $\mathrm{kcal} / \mathrm{mol}$ ) and utilization of the resulting amidyl radicals in a new catalytic protocol for alkene carboamination (Figure 1). ${ }^{7}$ These reactions, which install vicinal $\mathrm{C}-\mathrm{N}$ and $\mathrm{C}-\mathrm{C}$ bonds across an unactivated alkene in a single transformation, are complementary in scope to many established catalytic carboamination technologies and have the potential to simplify the synthesis of a range of complex heterocyclic compounds. Moreover, while most state of the art technologies in synthetic amidyl chemistry rely on radical generation via either $\mathrm{N}$ functionalized substrates ${ }^{8}$ or the use of strong stoichiometric oxidants, ${ }^{9}$ the reaction described here constitutes a rare example of catalytic amidyl generation via direct homolysis of the $\mathrm{N}-\mathrm{H}$ bond in a simple amide precursor. ${ }^{10}$ The design, scope, and mechanistic evaluation of the PCET process are described herein.

\section{Reaction design}

Our initial efforts focused on identifying combinations of Brønsted bases and excited-state oxidants that, while incapable of reacting with the amide substrates individually, are thermodynamically competent in combination to effect PCET homolysis of the $\mathrm{N}-\mathrm{H}$ bond in model amide 1 (Scheme 1). In these reactions, we envisioned that the Brønsted base would first form a hydrogen-bonded complex with the secondary amide substrate, modulating its oxidation potential to facilitate PCET with the excited state of the photoredox catalyst. The nascent amidyl radical intermediate would then cyclize onto the pendant olefin to form a new $\mathrm{C}-\mathrm{N}$ bond and an adjacent carbon-centered radical. This radical would in turn undergo intermolecular addition to an acrylate acceptor to form a new $\mathrm{C}-\mathrm{C}$ bond and an $a$-carbonyl radical that would accept an electron from the reduced state of the photocatalyst to furnish an enolate. Favorable proton transfer between the enolate and the conjugate acid produced in the PCET event would furnish the desired carboamination product and regenerate the catalytically active forms of the oxidant/base pair.

To identify effective catalyst combinations for $\mathrm{N}-\mathrm{H}$ homolysis, we made use of a simple thermodynamic formalism introduced by Mayer and co-workers that defines an effective bond strength ("BDFE") for any given base/oxidant pair as a function of the $\mathrm{p} K_{\mathrm{a}}$ and redox potential of its constituents (Figure 1) and a constant term relating to the energetics of proton reduction. ${ }^{11}$ In turn, these values enable the thermochemistry of any proposed PCET event to be estimated by comparing the effective BDFE of the chosen base/oxidant pair to the 
strength of the bond being homolyzed. Importantly, as these two key parameters are independent variables, the formal bond strength can be rationally varied with respect to the strength of the target bond. We tested the validity of this approach through combinatorial evaluation of five iridium photocatalysts and four Brønsted bases with effective bond strengths ranging from 80 to $108 \mathrm{kcal} / \mathrm{mol}$ in the carboamination of anilide $1(\mathrm{~N}-\mathrm{H}$ BDFE $=$ $99 \mathrm{kcal} / \mathrm{mol}$ ) (Table 1). ${ }^{12,13}$ In these experiments, we observed that combinations with "BDFE" values significantly lower than the strength of the substrate $\mathrm{N}-\mathrm{H}$ bond were not successful catalysts for carboamination (entries 1-9). However, all of the combinations with effective BDFEs approaching or exceeding the N-H BDFE of 1 resulted in catalytic generation of 2, though with varying degrees of efficiency (entries 10-20). Notably, all of the iridium complexes and bases evaluated proved active in at least one combination, including those with $\mathrm{p} K_{\mathrm{a}}$ values and potentials far removed from those of the amide substrate $\left(\mathrm{p} K_{\mathrm{a}} \sim 32, E_{\mathrm{p}}=+1.2 \mathrm{~V}\right.$ vs Fc/Fc $\mathrm{Fc}^{+}$in $\mathrm{MeCN}$ ) (entry 10). ${ }^{12,13}$ Taken together, these results are consistent with a PCET mechanism of amidyl formation (vide infra) and support the notion that thermochemistry is a principal determinant in the kinetic viability of $\mathrm{N}-\mathrm{H}$ activation. In addition, these studies highlight the ability of PCET to enable access to catalytically active $\mathrm{H}$ - acceptor systems with effective bond strengths higher than those attainable with any known molecular HAT catalysts (entry 20).

From the successful combinations tested, we elected to further study the

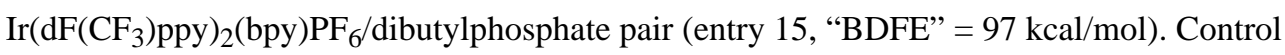
reactions omitting either the Ir photocatalyst or visible-light irradiation provided none of the desired carboamination product (entries 21 and 22). Similarly, reactions run in the absence of the phosphate base resulted in $<5 \%$ conversion of the amide starting material (entry 23). The carboamination reaction was also successful, though lower-yielding, when carried out at lower concentrations, with lower catalyst loadings, or with 1.1 equiv of the acrylate acceptor (entries 24-27).

\section{Substrate scope}

Using the optimal conditions outlined above, we next examined the scope of this process. On a preparative scale, carboamination of the model substrate $\mathbf{1}$ furnished amide $\mathbf{2}$ in $\mathbf{9 5 \%}$ isolated yield after $18 \mathrm{~h}$ of irradiation with blue light-emitting diodes (LEDs) at room temperature (rt) (Table 2). Carbamates were also excellent substrates, providing straightforward access to vicinal amino alcohol derivatives such as $\mathbf{3}$ from simple allylic alcohol starting materials. Structurally related urea and thiazolidinone products $\mathbf{4}$ and $\mathbf{5}$ could also be accessed in good yields. Notably, this method was also found to accommodate tetrasubstituted olefin substrates, providing access to products containing vicinal tertiary carbinamine and quaternary carbon centers, such as $\mathbf{6}$. This observation was extended to an endocyclic tetrasubstituted olefin substrate, furnishing spirocycle $\mathbf{7}$ in good yield with moderate diaster-eoselectivity. To the best of our knowledge, tetrasubstituted olefins are not substrates in any other reported catalytic carboamination technology. Fused bicyclic systems could also be generated using this method. For example, a cyclohexenol-derived carbamate was cyclized to furnish $\mathbf{8}$ in $86 \%$ yield as an 8:1 mixture of diastereomers at the quaternary carbon center. Additionally, a protected glucal substrate was successfully carboaminated to provide carbohydrate derivate $\mathbf{9}$ with high levels of diastereoselectivity. A carbamate 
substrate derived from an acyclic chiral allylic alcohol cyclized to provide access to transfused oxazolidinone $\mathbf{1 0}$ with excellent diastereoselectivity. Geminal substitution adjacent to the olefin is tolerated and enables the use of both monosubstituted and 1,2disubstituted olefin substrates, with moderate diastereoselectivity observed in the latter case (11 and 12). Simple monosubstituted olefins could be also carboaminated efficiently when more activated olefin acceptors were employed (13).

With respect to the arylamine component, numerous para-substituted substrates were accommodated (14-17), including both electron-rich and electron-deficient examples. Similarly, substrates bearing both meta- and ortho-substituted arenes could be carboaminated in good yields (18 and 19). In addition, heterocyclic arenes such as pyridine and benzothiazole could be incorporated into the amide moiety and cyclized with good efficiency (20 and 21). Notably, the potential required for direct ET oxidation of $p$-CN carbamates such as $\mathbf{1 5}$ is more than $600 \mathrm{mV}$ more positive than that of the $\operatorname{Ir}(\mathrm{III})$ excited state $\left(E_{1 / 2}=+1.0 \mathrm{~V}\right.$ vs $\mathrm{Fc} / \mathrm{Fc}^{+}$in $\left.\mathrm{MeCN}\right)$, highlighting the ability of simple hydrogenbonding interactions to facilitate otherwise challenging charge transfer events. ${ }^{14,15}$ Lastly, a variety of electron-deficient olefin partners were found to effectively couple, including methyl acrylate, methyl vinyl ketone, acrolein, acrylonitrile, and 2-vinylpyridine (20-23).

\section{Mechanism of amidyl formation}

To assess the role of PCET in these reactions, we studied the mechanism of amidyl formation using luminescence quenching techniques and $N$-phenyl-acetamide (26) as a model substrate. Stern-Volmer analysis revealed that $\mathbf{2 6}\left(E_{\mathrm{p}}=+1.2 \mathrm{~V}\right.$ vs Fc/Fc $\mathrm{Fc}^{+}$in $\left.\mathrm{MeCN}\right)$

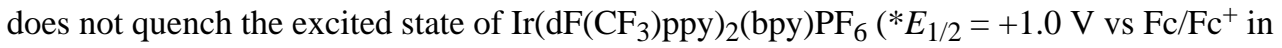
$\mathrm{MeCN}$ ) in acetonitrile at $25{ }^{\circ} \mathrm{C} .{ }^{14-16}$ However, solutions containing both amide 26 and tetrabuty-lammonium dibutylphosphate resulted in a significant decrease in the observed emission intensity. Variation of the phosphate base and amide concentrations in these assays demonstrated that the rate law for the quenching process exhibits a first-order kinetic dependence on the concentration of each component. Additionally, an isotope effect of 1.15 \pm 0.04 was observed in independent experiments conducted with the $\mathrm{N}-\mathrm{H}$ and $\mathrm{N}-\mathrm{D}$ isotopologues of $\mathbf{2 6}$, consistent with the notion that the labeled bond plays a specific role in the quenching process. ${ }^{17}$ Notably, the phosphate base alone was also found to weakly quench the Ir excited state $\left(k_{\mathrm{SV}}=41 \mathrm{M}^{-1}\right)$, but not sufficiently to account for the much greater degree of quenching observed when amide $\mathbf{2 6}$ was also present in solution $\left(k_{\mathrm{SV}}=\right.$ $\left.731 \mathrm{M}^{-1}\right)$.

While the above results indicate that the excited-state iridium complex does not oxidize the amide substrate directly, they are consistent in principle with either concerted PCET activation or rate-limiting deprotonation of the amide substrate by the phosphate base followed by fast oxidation of the resulting anilide anion. However, the large $\mathrm{p} K_{\mathrm{a}}$ difference between the amide and the phosphate $\left(\Delta \mathrm{p} K_{\mathrm{a}} \sim 20\right)$ suggests that the latter pathway would not be kinetically competitive with luminescent decay of the Ir excited state $(\tau=2.3 \mu \mathrm{s}$ in $\mathrm{MeCN}$ at rt). ${ }^{14}$ As the feasibility of both sequential transfer mechanisms can be discounted, the measured rate law and isotope effect are consistent with a concerted PCET mechanism of amidyl formation. ${ }^{18}$ 
In conclusion, we have developed a novel PCET-based protocol for alkene carboamination. Notably, these studies demonstrate that concerted multisite PCET is a viable mechanism for the direct homolytic activation of strong $\mathrm{N}-\mathrm{H}$ bonds, providing catalytic access to amidyl radical intermediates from simple anilide starting materials. Differential hydrogen-bonding ability enables these PCET activations to be completely chemoselective for the $\mathrm{N}-\mathrm{H}$ bond even when much weaker allylic $\mathrm{C}-\mathrm{H}$ bonds are present in the same substrates. Additionally, the qualitative success of effective BDFEs in enabling catalyst selection suggests that this simple metric will become an enabling tool in PCET reaction design. ${ }^{19}$ These results provide further support for the view that concerted PCET mechanisms can be translated to small-molecule catalysis platforms and enable the development of new synthetic methods.

\section{Supplementary Material}

Refer to Web version on PubMed Central for supplementary material.

\section{Acknowledgments}

Financial support was provided by Princeton University and the NIH (R01 GM113105). R.R.K. is a Fellow of the Alfred P. Sloan Foundation.

\section{References}

1. (a) Evans MG, Polanyi M. Trans Faraday Soc. 1938; 34:11.(b) Kochi, JK., editor. Free Radicals. Wiley; New York: 1973. (c) Roth JP, Yoder JC, Won TJ, Mayer JM. Science. 2001; 294:2524. [PubMed: 11752572] (c) Mayer JM. Acc Chem Res. 2011; 44:36. [PubMed: 20977224]

2. Luo, YR. Handbook of Bond Dissociation Energies in Organic Compounds. CRC Press; Boca Raton, FL: 2003.

3. (a) Reece SY, Nocera DG. Annu Rev Biochem. 2009; 78:673. [PubMed: 19344235] (b) Mayer JM. Annu Rev Phys Chem. 2004; 55:363. [PubMed: 15117257] (c) Hammes-Schiffer S, Stuchebrukhov AA. Chem Rev. 2010; 110:6939. [PubMed: 21049940] (d) Weinberg DR, Gagliardi CJ, Hull JF, Murphy CF, Kent CA, Westlake BC, Paul A, Ess DH, McCafferty DG, Meyer TJ. Chem Rev. 2012; 112:4016. [PubMed: 22702235]

4. For discussions of the role of hydrogen-bonding in concerted PCET, see: Turro C, Chang CK, Leroi GE, Cukier RI, Nocera DG. J Am Chem Soc. 1992; 114:4013.Kirby J, Roberts J, Nocera DG. J Am Chem Soc. 1997; 119:9230. Young ER, Rosenthal J, Hodgkiss JM, Nocera DG. J Am Chem Soc. 2009; 131:7678. [PubMed: 19489645] Sjodin M, Irebo T, Utas JE, Lind J, Merenyi G, Akermark B, Hammarstrom L. J Am Chem Soc. 2006; 128:13076. [PubMed: 17017787] Markle TF, Mayer JM. Angew Chem, Int Ed. 2008; 47:738.

5. (a) Maki T, Araki Y, Ishida Y, Onomura O, Matsumura Y. J Am Chem Soc. 2001; 123:3371. [PubMed: 11457075] (b) Rhile IJ, Markle TF, Nagao H, DiPasquale AG, Lam OP, Lockwood MA, Rotter K, Mayer JM. J Am Chem Soc. 2006; 128:6075. [PubMed: 16669677]

6. (a) Fecenko CJ, Meyer TJ, Thorp H. J Am Chem Soc. 2006; 128:11020. [PubMed: 16925408] (b) Fecenko CJ, Thorp H, Meyer TJ. J Am Chem Soc. 2007; 129:15098. [PubMed: 17999500] (c) Schrauben JN, Cattaneo M, Day TC, Tenderholt AL, Mayer JM. J Am Chem Soc. 2012; 134:16635. [PubMed: 22974135] (d) Pizano AA, Nocera DG, Yang JL. Chem Sci. 2012; 3:2457. [PubMed: 23495362]

7. (a) Hegedus LS, Allen GF, Olsen DJ. J Am Chem Soc. 1980; 102:3583.(b) Ney JE, Wolfe JP. Angew Chem, Int Ed. 2004; 43:3605.(c) Ney JE, Wolfe JP. J Am Chem Soc. 2005; 127:8644. [PubMed: 15954769] (d) Rosewall CF, Sibbald PA, Liskin DV, Michael FE. J Am Chem Soc. 2009; 131:9488. [PubMed: 19545153] (e) Zeng W, Chemler SR. J Am Chem Soc. 2007; 129:12948. [PubMed: 17918850] (f) Liwosz TW, Chemler SR. J Am Chem Soc. 2012; 134:2020. [PubMed: 22257169] (g) Scarborough CC, Stahl SS. Org Lett. 2006; 8:3251. [PubMed: 16836378] 
(h) Yip KT, Yang M, Law KL, Zhu NY, Yang D. J Am Chem Soc. 2006; 128:3130. [PubMed: 16522078]

8. (a) Fallis AG, Brinza IM. Tetrahedron. 1997; 53:17543.(b) Zard SZ. Synlett. 1996; 1996:1148.(c) Kemper J, Studer A. Angew Chem, Int Ed. 2005; 44:4914.(d) Guin J, Fröhlich R, Studer A. Angew Chem, Int Ed. 2008; 47:779.(e) Gagosz F, Moutrille C, Zard SZ. Org Lett. 2002; 4:2707. [PubMed: 12153215] (f) Lin X, Stien D, Weinreb SM. Tetrahedron Lett. 2000; 41:2333.(g) Esker JL, Newcomb M. Tetrahedron Lett. 1993; 34:6877.(h) Esker JL, Newcomb M. J Org Chem. 1993; 58:4933.(i) Chen K, Richter JM, Baran PS. J Am Chem Soc. 2008; 130:7247. [PubMed: 18481847]

9. (a) Nicolaou KC, Baran PS, Zhong YL, Barluenga S, Hunt KW, Kranich R, Vega JA. J Am Chem Soc. 2002; 124:2233. [PubMed: 11878977] (b) Hernandez R, Medina MC, Salazar JA, Suarez E, Prange T. Tetrahedron Lett. 1987; 28:2533.(c) Freire R, Martin A, Perez-Martin I, Suarez E. Tetrahedron Lett. 2002; 43:5113.(d) Janza B, Studer A. J Org Chem. 2005; 70:6991. [PubMed: 16095334]

10. Li recently reported a catalytic alkene aminofluorination wherein amidyls are generated from anilides via oxidation with a $\mathrm{Ag}(\mathrm{III})$ fluoride complex. See: Li Z, Song L, Li C. J Am Chem Soc. 2013; 135:4640. [PubMed: 23506151]

11. (a) Warren JJ, Tronic TA, Mayer JM. Chem Rev. 2010; 110:6961. [PubMed: 20925411] (b) Waidmann CR, Miller AJ, Ng CWA, Scheuermann ML, Porter TR, Tronic TA, Mayer JM. Energy Environ Sci. 2012; 5:7771.(c) Tarantino KT, Liu P, Knowles RR. J Am Chem Soc. 2013; 135:10022. [PubMed: 23796403] (d) Yayla H, Knowles RR. Synlett. 2014; 25:2819.(e) Nomrowski J, Wenger OS. Inorg Chem. 2015; 54:3680. [PubMed: 25781364]

12. Cheng JP, Zhao YY. Tetrahedron. 1993; 49:5267.

13. See the Supporting Information for potential and $\mathrm{p} K_{\mathrm{a}}$ data used in the effective BDFE calculations. The value of $C_{\text {solv }}$ for $\mathrm{MeCN}$ used in these calculations was $54.9 \mathrm{kcal} / \mathrm{mol}$. ${ }^{11 \mathrm{a}}$

14. Hanss D, Freys JC, Bernardinelli GR, Wenger OS. Eur J Inorg Chem. 2009; 2009:4850.

15. See the Supporting Information for voltammetry data.

16. Stern-Volmer experiments were carried out in $\mathrm{MeCN}$ to allow comparisons to literature potential, lifetime, and $\mathrm{p} K_{\mathrm{a}}$ data. Carboamination of 1 under standard conditions in $\mathrm{MeCN}$ was effective and provided 2 in $42 \%$ yield.

17. For examples and theoretical justification of small isotope effects in multisite PCET reactions, see: Warren JJ, Menzeleev AR, Kretchmer JS, Miller TF III, Gray HB, Mayer JM. J Phys Chem Lett. 2013; 4:519. [PubMed: 23493584] Warren JJ, Mayer JM. J Am Chem Soc. 2011; 133:8544. [PubMed: 21524059] (c) Reference 6c. Hammes-Schiffer S, Soudackov AV. J Phys Chem B. 2008; 112:14108. [PubMed: 18842015] Megiatto JD Jr, Méndez-Hernández DD, Tejeda-Ferrari ME, Teillout AL, Llansola-Portolés MJ, Kodis G, Poluektov OG, Rajh T, Mujica V, Groy TL, Gust D, Moore TA, Moore AL. Nat Chem. 2014; 6:423. [PubMed: 24755594] Edwards SJ, Soudackov AV, Hammes-Schiffer S. J Phys Chem A. 2009; 113:2117. [PubMed: 19182970]

18. For examples of concerted PCET with excited-state redox partners, see: Wenger OS. Acc Chem Res. 2013; 46:1517. [PubMed: 23402212] Gagliardi CJ, Westlake BC, Kent CA, Paul JJ, Papanikolas JM, Meyer TJ. Coord Chem Rev. 2010; 254:2459.

19. As pointed out by a reviewer, the thermochemical considerations reflected in the effective BDFE formalism are best viewed as a necessary but not a sufficient condition to ensure a given PCET activation. 
Oxidative PCET Activation of Amide N-H Bonds

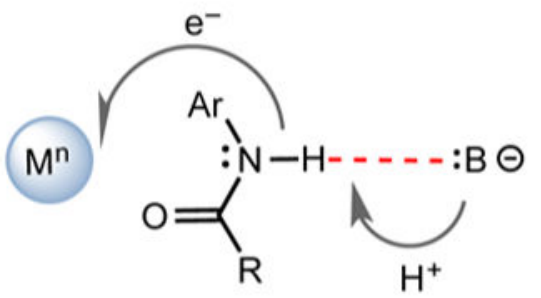

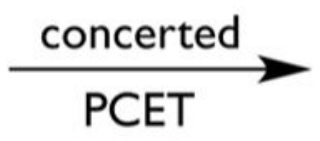<smiles>[M]C1CCCCC1</smiles><smiles></smiles>

$\mathrm{N}-\mathrm{H}$ BDFE for $\mathrm{N}$-aryl amide $\sim 100 \mathrm{kcal} / \mathrm{mol}$

PCET 'BDFE' $(\mathrm{kcal} / \mathrm{mol})=1.37 \mathrm{pK}_{\mathrm{a}}(\mathrm{H}-\mathrm{B})+23.06 E\left(\mathrm{M}^{\mathrm{n}}\right)+\mathrm{C}_{\text {solv }}$

\section{Catalytic Alkene Carboamination Enabled by PCET}<smiles>[R]C([R])=CCCC(=O)N[Al]</smiles>

$\stackrel{\text { PCET }}{\longrightarrow}$
Ir(III) redox cat.

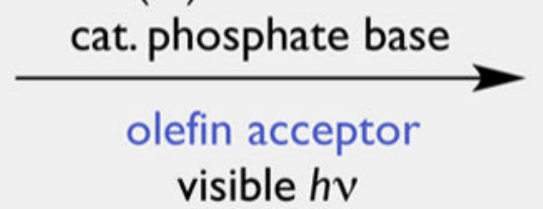

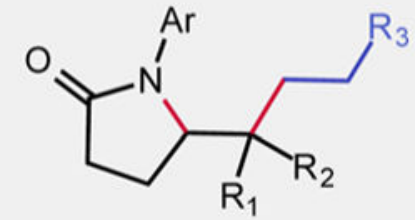

(1)

Figure 1.

PCET activation of amide $\mathrm{N}-\mathrm{H}$ bonds and application to the development of a catalytic protocol for alkene carboamination. 


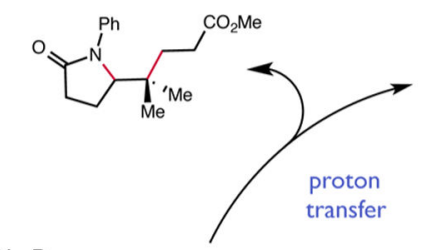

$\mathrm{M}^{\mathrm{N}}$
$: \mathrm{B} \Theta$
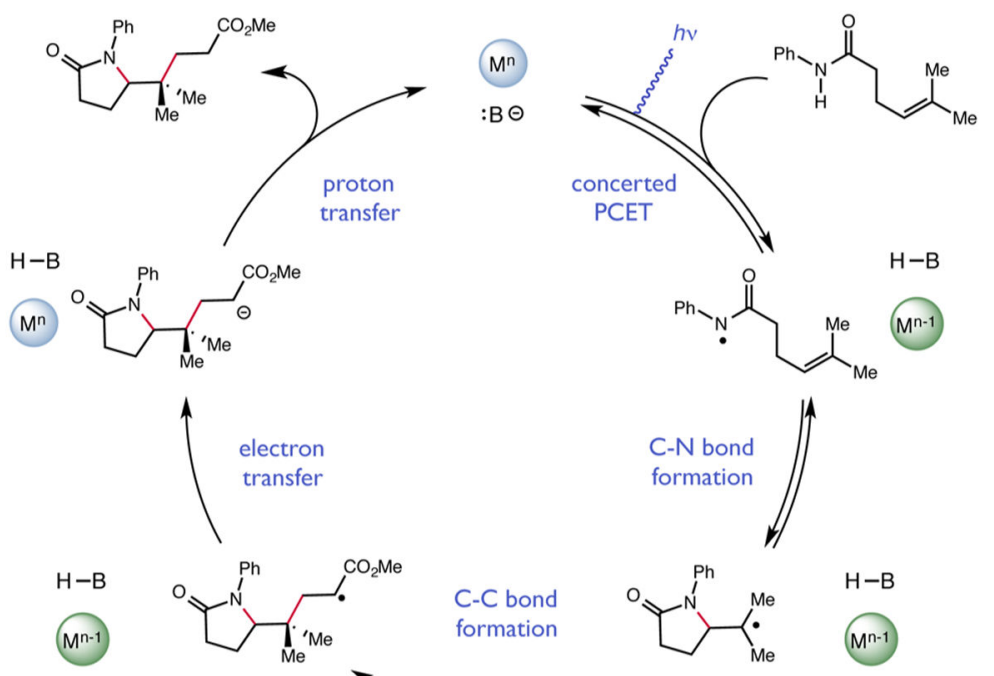

C-C bond formation

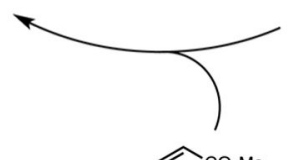

Scheme 1.

Proposed Catalytic Cycle
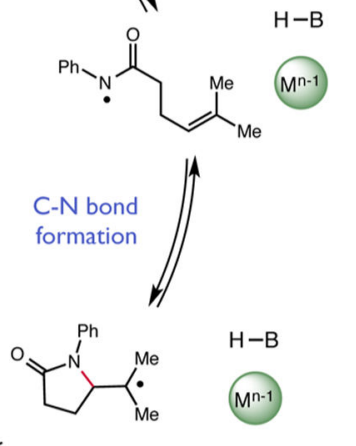
Table 1

\section{Reaction Optimization $^{a}$}

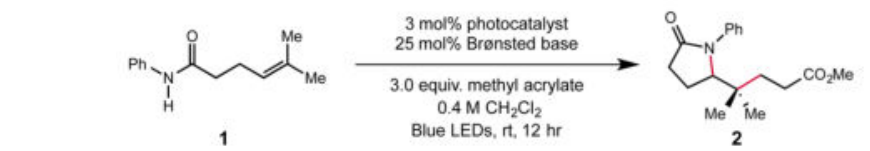

\begin{tabular}{|c|c|c|c|c|}
\hline Entry & Photocatalyst & Base & "BDFE" $b$ & Yield $(\%)$ \\
\hline 1 & $\operatorname{Ir}(\text { ppy })_{2}($ phen $) \mathrm{PF}_{6}$ & $\mathrm{NBu}_{4} \mathrm{OP}(\mathrm{O})(\mathrm{OBu})_{2}$ & 80 & 0 \\
\hline 2 & $\operatorname{Ir}(\text { ppy })_{2}($ phen $) \mathrm{PF}_{6}$ & lutidine & 82 & 0 \\
\hline 3 & $\operatorname{Ir}(\mathrm{Fmppy})_{2}(\mathrm{dtbbpy}) \mathrm{PF}_{6}$ & $\mathrm{NBu}_{4} \mathrm{OP}(\mathrm{O})(\mathrm{OBu})_{2}$ & 82 & 0 \\
\hline 4 & $\operatorname{Ir}(\mathrm{Fmppy})_{2}(\mathrm{dtbbpy}) \mathrm{PF}_{6}$ & lutidine & 83 & 0 \\
\hline 5 & $\operatorname{Ir}(\text { Fmppy })_{2}($ phen $) \mathrm{PF}_{6}$ & $\mathrm{NBu}_{4} \mathrm{OP}(\mathrm{O})(\mathrm{OBu})_{2}$ & 83 & trace \\
\hline 6 & $\operatorname{Ir}(\text { Fmppy })_{2}($ phen $) \mathrm{PF}_{6}$ & lutidine & 85 & 0 \\
\hline 7 & $\operatorname{Ir}(\mathrm{ppy})_{2}(\mathrm{phen})\left(\mathrm{PF}_{6}\right)$ & DMAP & 87 & trace \\
\hline 8 & $\operatorname{Ir}(\mathrm{Fmppy})_{2}(\mathrm{dtbbpy}) \mathrm{PF}_{6}$ & DMAP & 89 & 0 \\
\hline 9 & $\operatorname{Ir}(\text { Fmppy })_{2}($ phen $) \mathrm{PF}_{6}$ & DMAP & 90 & 6 \\
\hline 10 & $\operatorname{Ir}(\text { ppy })_{2}($ phen $) \mathrm{PF}_{6}$ & $\mathrm{NBu}_{4} \mathrm{OBz}$ & 92 & 20 \\
\hline 11 & $\operatorname{Ir}\left(\mathrm{dF}\left(\mathrm{CF}_{3}\right) \text { ppy }\right)_{2}(\mathrm{dtbbpy}) \mathrm{PF}_{6}$ & $\mathrm{NBu}_{4} \mathrm{OP}(\mathrm{O})(\mathrm{OBu})_{2}$ & 92 & 76 \\
\hline 12 & $\operatorname{Ir}\left(\mathrm{dF}\left(\mathrm{CF}_{3}\right) \mathrm{ppy}\right)_{2}(\mathrm{dtbbpy}) \mathrm{PF}_{6}$ & lutidine & 93 & 22 \\
\hline 13 & $\operatorname{Ir}(\mathrm{Fmppy})_{2}(\mathrm{dtbbpy}) \mathrm{PF}_{6}$ & $\mathrm{NBu}_{4} \mathrm{OBz}$ & 93 & 56 \\
\hline 14 & $\operatorname{Ir}(\text { Fmppy })_{2}($ phen $) \mathrm{PF}_{6}$ & $\mathrm{NBu}_{4} \mathrm{OBz}$ & 95 & 35 \\
\hline 15 & $\operatorname{Ir}\left(\mathrm{dF}\left(\mathrm{CF}_{3}\right) \text { ppy }\right)_{2}(\mathrm{bpy}) \mathrm{PF}_{6}$ & $\mathrm{NBu}_{4} \mathrm{OP}(\mathrm{O})(\mathrm{OBu})_{2}$ & 97 & 92 \\
\hline 16 & $\operatorname{Ir}\left(\mathrm{dF}\left(\mathrm{CF}_{3}\right) \mathrm{ppy}\right)_{2}(\mathrm{bpy}) \mathrm{PF}_{6}$ & lutidine & 98 & 24 \\
\hline 17 & $\operatorname{Ir}\left(\mathrm{dF}\left(\mathrm{CF}_{3}\right) \mathrm{ppy}\right)_{2}(\mathrm{dtbbpy}) \mathrm{PF}_{6}$ & DMAP & 99 & 34 \\
\hline 18 & $\operatorname{Ir}\left(\mathrm{dF}\left(\mathrm{CF}_{3}\right) \mathrm{ppy}\right)_{2}(\mathrm{bpy}) \mathrm{PF}_{6}$ & DMAP & 103 & 16 \\
\hline 19 & $\operatorname{Ir}\left(\mathrm{dF}\left(\mathrm{CF}_{3}\right) \mathrm{ppy}_{2}\right)_{2}(\mathrm{dtbbpy}) \mathrm{PF}_{6}$ & $\mathrm{NBu}_{4} \mathrm{OBz}$ & 104 & 76 \\
\hline 20 & $\operatorname{Ir}\left(\mathrm{dF}\left(\mathrm{CF}_{3}\right) \mathrm{ppy}\right)_{2}(\mathrm{bpy}) \mathrm{PF}_{6}$ & $\mathrm{NBu}_{4} \mathrm{OBz}$ & 108 & 50 \\
\hline Entry & \multicolumn{2}{|c|}{ Change from best conditions (entry 15 ) } & & Yield $(\%)$ \\
\hline 21 & \multicolumn{2}{|l|}{ no light } & & 0 \\
\hline 22 & \multicolumn{2}{|c|}{ no photocatalyst } & & 0 \\
\hline 23 & \multicolumn{2}{|c|}{ no $\mathrm{NBu}_{4} \mathrm{OP}(\mathrm{O})(\mathrm{OBu})_{2}$} & & $<5$ \\
\hline 24 & \multicolumn{2}{|c|}{$1 \mathrm{~mol} \% \operatorname{Ir}\left(\mathrm{dF}\left(\mathrm{CF}_{3}\right) \mathrm{ppy}\right)_{2}(\mathrm{bpy}) \mathrm{PF}_{6}$} & & 76 \\
\hline 25 & \multicolumn{2}{|c|}{$10 \mathrm{~mol} \% \mathrm{NBu}_{4} \mathrm{OP}(\mathrm{O})(\mathrm{OBu})_{2}$} & & 78 \\
\hline 26 & \multicolumn{2}{|c|}{1.1 equivalents of acrylate } & & 68 \\
\hline 27 & \multicolumn{2}{|c|}{$0.1 \mathrm{M}$ in $\mathrm{CH}_{2} \mathrm{Cl}_{2}$} & & 80 \\
\hline
\end{tabular}

${ }^{a}$ Optimization reactions were performed on a $0.05 \mathrm{mmol}$ scale. Yields were determined by ${ }^{1} \mathrm{H}$ NMR analysis of the crude reaction mixtures relative to an internal standard.

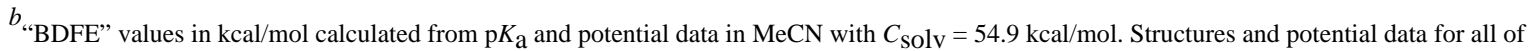
the photocatalysts are included in the Supporting Information.

$J$ Am Chem Soc. Author manuscript; available in PMC 2015 November 13. 


\section{Table 2}

Substrate Scope Studies ${ }^{a}$

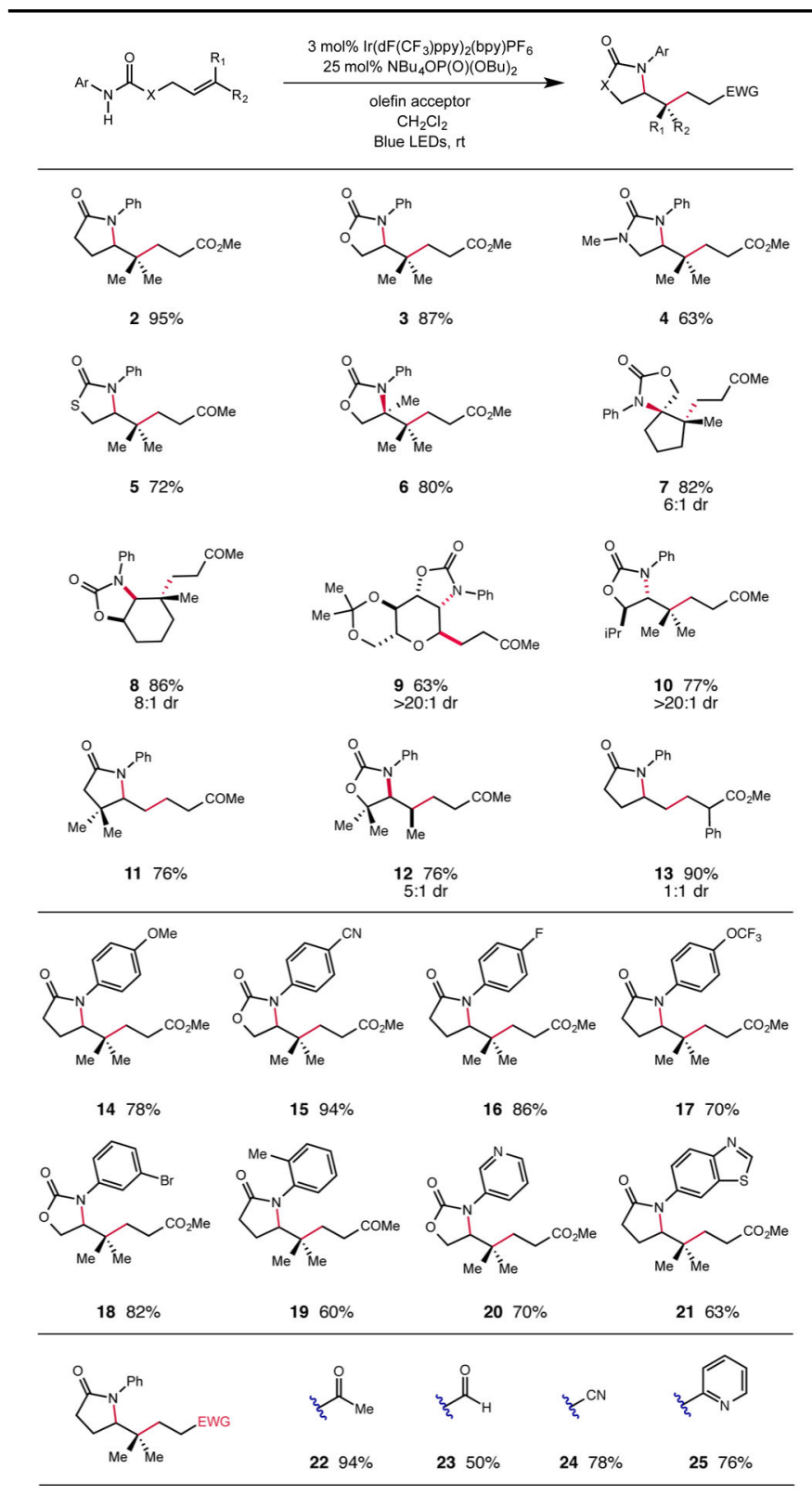

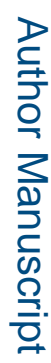

${ }^{a}$ Reactions were performed on a $0.5 \mathrm{mmol}$ scale. Yields are for purified materials and are averages of two experiments. Diastereomeric ratios were determined by ${ }^{1} \mathrm{H}$ NMR analysis of the crude reaction mixtures.

$J$ Am Chem Soc. Author manuscript; available in PMC 2015 November 13. 